\title{
INDUSTRIAL RELATIONS IN THE PERSPECTIVE OF JUSTICE THEORY BY JOHN RAWLS
}

\author{
Ari Hernawan* \\ Hukum Perdata, Fakultas Hukum Universitas Gadjah Mada, Yogyakarta \\ Jalan Sosio Yustisia Number 1, Bulaksumur, Sleman, D.I. Yogyakarta 55281
}

\begin{abstract}
Conflict of interest between employee and employer has a complexity since its biopsychology and sosioeconomic in nature. As its implication, it is difficult to create a consensus between two different interest within a legal perspective. Justice theory by John Rawls has answered the respective problem by giving legal priority upon the group of people who have less capacity in sosial and economic. According to John Rawls, law shall give orientation toward marginalized group. In industrial relations, law shall take side upon the employee who are in subordinate position.
\end{abstract}

Keywords: industrial relations, justice, theory of John Rawls.

\section{Intisari}

Pertentangan kepentingan antara pekerja dan pengusaha memiliki kompleksitas karena bersifat biopsikologis dan sosio-ekonomi. Sebagai implikasinya, sulit mempertemukan dua kepentingan yang berbeda tersebut dalam satu rumusan hukum. Teori keadilan dari John Rawls telah menjawab persoalan tersebut dengan memberi prioritas hukum kepada orang-orang yang secara sosial ekonomi kurang beruntung. Hukum menurut John Rawls harus berorientasi kepada kelompok marjinal. Dalam hubungan industrial, hukum harus berpihak kepada pekerja yang berada dalam posisi subordinat.

Kata Kunci: hubungan industrial, keadilan, teori John Rawls.

\section{Pokok Muatan}

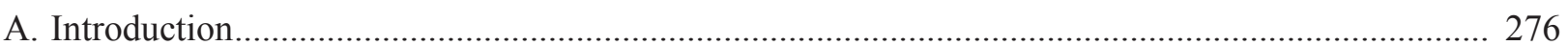

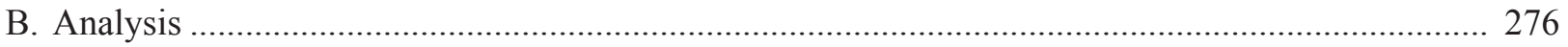

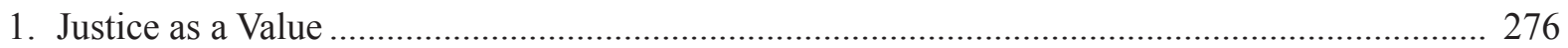

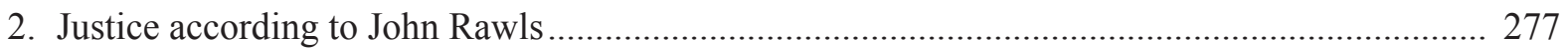

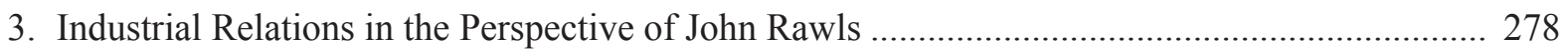

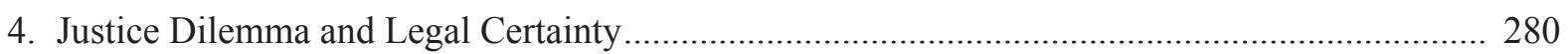

5. Potential for the Circumstantial Abuse in Industrial Relations .................................................. 282

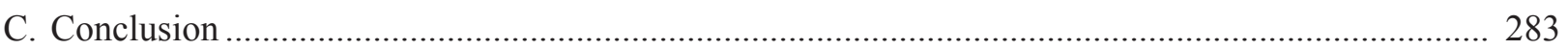

Correspondence address: ari.hernawan@rocketmail.com 


\section{A. Introduction}

In the industrial relations, the employee and employer are two powers pulling each other, or even against each other at times, because both sides have distinctive concerns in maintaining work relationships. The logic of labour market which provides disproportionate supply and demand has caused imbalanced relations, or the marginalization of working class. Labour law as a manifestation of industrial relations has not yet provided sufficient protection towards the employees in a subordinate position. Labour law, instead, is more of representing manpower policies, which tend to be made in line with economic policies. This leads to the creation of injustice manpower regulations to the employees, because they only become an inseparable part of such economic policies.

In its implementation, the imbalance of relations and injustice has created a conflict of interests between legal certainty and justice, because the existing labour law products are said to not reflect the reality of employees' lives and the value of justice in the society. The problem is, formulating an impartial law product has never been an easy matter when the law itself is a political result of how different interests clash with each other. All this time, the products of labour law are mostly political compromises dominated by entrepreneurs, who indeed are benefited by eases of access to all sorts of resources, including the practice of political lobbying to the lawmakers.

It is undoubtedly difficult to formulate two different interests in a general form of law product. Such issue has raised a question on the format of just law. There have been numerous theories on justice emerging as trials on answering the question of just law. One of those modern justice theories is the one coming from John Rawls, which is considered to be able to answer the question on law and justice when two interests conflict. This writing analyses the justice theory by John Rawls, associated with the imbalance in industrial relations, which has been difficult to answer by the previous justice theories.

\section{B. Analysis \\ 1. Justice as a Value}

Labour law as a representation of employeeemployer relations is not a neutral and autonomousindependent law; neither is it a law that sets the involved parties on an equal footing. In labour law, there is no such thing as neutral or sterile from the struggle within it: from the legislative phase dominated by political elements until the execution phase which is often hard to be done, caused by the magnitude of trust and disobedience of law. It being said, industrial relations between employee and employer is not value-free. Rawls's thought was also related to the fact that justice is a value, therefore to understand Rawls's justice theory one must analyse the concept of value in justice.

Concepts of justice throughout history are quite an assortment. Justice, in its historical rotation, is interpreted variably, starting from justice as a cardinal virtue or as an idea. Justice in its development nowadays is no longer conceptualized as an idea, but more as a value. It is an objective reality beyond humanity or subjective consciousness in human beings in the form of attitude. A value is created when there is a mutual relationship between objective reality and subjective consciousness. A particular value would be born if there is a human attitude in concern of a certain issue and simultaneously there shall also be an answer to such concern a human has.

Conceptually, a value is understood in two ways: subjective and objective. ${ }^{1}$ There shall be a value when there are fulfilments of, objectively, the factors of utility and importance, and subjectively, the factors of need and estimation. Subjective consciousness within human beings can explain why there are differences of values between individuals or groups, because the needs demanding 
to be fulfilled are different with each individual or group. Value is not equal to belief or norm, but it is a preference over something more desired and not a believed knowledge. It is different with norm because it is a general standard, while a norm is already a fairly through rule of behaviour.

Based on the given explanation, it is true to state that justice is seen as a value. Justice as a value becomes a goal agreed mutually by the people of a society, and the achievement of such goal is done for the sake of justice itself. ${ }^{2}$ The various concepts of justice, inclusive of justice as a value, are a consequence of justice theory substance developed by justice thinkers, and one of the world most influential justice thinkers is John Rawls.

\section{Justice According to John Rawls}

According to Rawls, the issue of justice emerges when there are conflicting demands within a society, and justice becomes necessary to even them up. Justice, in Rawls's theory, can be acquired when the members of a society respect what he calls as "primary goods", or the most important matters of people. Rawls stated that justice shall emerge when: Firstly, every person has the equal rights over basic liberties; and Secondly, social and economic difference is arranged in such a way that: (a) it gives most benefits to those most disadvantaged; and (b) here are open and equal chances to everyone in relation to employment. ${ }^{3}$

The first aspect covers the problems related to the people's equality over basic liberties. The second aspect is in regard to the inequality of economy and social chances. Rawls claimed that the strength of his justice theory is supported by two principles: independence priority and the fact that not all the inequalities are justified to the most disadvantaged. Those two principles are in lexical order so that the claim of the second principle can only be made after the claim of the first. This means that the claim of independence shall be fulfilled first, and then the inequality claim can be in effect. The aforementioned first principle of justice is regarding the need of equal distribution of basic liberties, which include the right to vote and hold a position in the government, freedom of expression and assembly, freedom of conscience, freedom of thought, and freedom of self.

The second principle of justice is concerned with power, position, social status, income and wealth. In this case, the theory of Rawls adheres to the principle of distinction. In human cooperation, the only viable principle is the one that accepts inequality only if it lasts for the benefit of those who are most disadvantaged. According to Rawls, after those two justice principles are set, they depend on the application in practice of preparing public regulations. He said that the task of social institutions and politics is to maintain and enhance the freedom and well-being of individuals.

Rawls's two principles of justice is a political concept which Rawls called as egalitarian liberalism. Egalitarian liberalism is supported by at least three elements, namely the guarantee of political freedom value, equal opportunity, and the principle of distinction that emphasizes the orientation of similarities and opportunities to the most disadvantaged communities. Rawls stated that the last test on theory of justice is not only about whether the similarities and the opportunity are actually guaranteed and protected, but also about whether residents can take advantage of the rights and opportunities. The meaning of "independence" shall be distinguished from "value of independence". "Independence" can enforce the application of the principle of equality, where the freedom of independence is applicable to all. Meanwhile, "value of independence" cannot be equal to everyone, as there is no issue of equality. This is a problem caused by a variety of social problems such as poverty and ignorance. All those

The Liang Gie, 1982, Teori-Teori Keadilan, Supersukses, Yogyakarta, pp. 12-14.

John Rawls, 1971, A Theory of Justice, The Belknap Press of Stanford University Press, Cambridge, Massachusetts, pp.72-74 and pp. 386387. 
can cause people to not exercise the rights and opportunities guaranteed by the principle of justice.

Furthermore, Rawls believed that justice is not limited to only moral concepts of its individuals, but also the mechanism of achieving such justice, inclusive of how the law shall be able to support the system. Justice is a value that directs every involved part to provide the protection towards legally guaranteed rights (the element of right). Such protection, ultimately, shall give benefit to every individual (the element of benefit). Rawls put the priority on independence and equality, and merged them in the substantial justice. Rawls stated that the success of economic development is related to not only the increase in prosperity and the decrease in poverty, but also-and especially, the increase in freedom. Rawls's justice theory fundamentally aims to overcome the controversy on the dilemma between independence and equality, which always seemed impossible to be incorporated together.

Based on such explanation, it is clear that justice according to Rawls is a rational justice, taking its source of thought from general principles of rationality on justice. Rational justice essentially tries to answer the issue on justice through scientific explaining based on rational reasons. The justice principle offered by Rawls illustrates that he was also influenced by a main justice school, namely utilitarianism. This school brings back the issue of justice to the principle of utility. Utilitarianism aims to improve human welfare and that moral rules must be tested against the benefit of the consequences. Utilitarianism is essentially linked directly with the goal of advancing the welfare of its citizens.

Utilitarianism emphasizes on the results achieved from the distribution of resources, which means that a distribution of resources can be declared fair if the result achieved is the greatest good for the largest amount. There are two meanings that can be drawn from the principle of the greatest good for the largest amount that brings implication for the different concept of justice, that is seen from the comparison between positive and negative impacts for society or the individual, and seen from the comparison between the results obtained with the costs incurred for getting such results.

In connection with Rawls's theory of justice, if seen from a comparison between the positive and negative impacts for society or the individual, then the distribution can be expressed as only having a positive impact if everyone is equally able to acquire and enjoy the resources that exist, or if existing resources can be obtained and enjoyed by a group of people who are socially or economically less advantaged, or if it can be enjoyed by a group of people who suffered losses from the actions of others. Differentiation of target group distribution of these resources poses the kind of justice aimed to be formed. ${ }^{4}$

If the distribution of the resources is intended to bring the same positive impact to everyone, then the distribution will create commutative justice. In contrast, if the distribution of the resources intended to bring positive impact to the communities socioeconomically weaker or less advantaged, then the direction is the creation of corrective justice. If the distribution of the resources is intended to provide a positive impact on a group of people who suffered losses due to the actions of other parties or groups, then the distribution is directed to compensatory justice, meaning that disadvantaged groups are entitled to reimbursement for profit or enjoyment is lost due to the actions of others.

\section{Industrial Relations in The Perspective of John Rawls}

Those three forms of justice can be covered in a concept called social justice. This concept implies that the distribution of resources should be directed to the creation of social welfare, especially for the lower groups or the economically and socially weak. This means that the distribution of resources should be directed to the creation of 
equitable distribution of available resources so that groups of people who are economically and socially weak can be alleviated from poverty and reduced inequality among socio-economic groups. Distribution of existing resources can be said to be socially just if the distribution of socio-economic groups improves the lives of the poor so that the level of socio-economic gap between communities can be narrowed.

Therefore, what is the relevance of Rawls's theory of justice to industrial relations? It is indeed difficult to deny that unequal dialectic relationship between actors in industrial relations still happens until this day. Such unequal dialectic relationship is a potential trigger of conflict. The conflict in industrial societies according to Marx is regarded as the primary cause of social inequality and alienation of industrial relations between the capitalist class (bourgeoisie) and proletariat (workers). In Marx's theory that embraces social fact paradigm, there are some aspects of social reality that cannot be ignored, such as the recognition of the existence of class structure in the society, conflicting economic interests among the people in different classes, the great influence of economic class position to one's lifestyle as well as various forms of awareness and influence of class conflict. ${ }^{5}$

In causing changes to the social structure, Marx emphasized on the economic basis for social class. The thought Marx had for social class was affected by industrialization in the nineteenth century that gave birth to the phenomenon of the suffering working class life, while capital owners enjoy the luxuries of life. Marx's predictions have said that there would not be any changes in the social structure except by revolution. The revolution Marx mentioned was not intended to process bloodshed. Marx divided human consciousness into a "false consciousness" and "true consciousness". Marx pointed out and believed that the compliance of the workers on the job is a false consciousness, because in them there is a real need for other needs that they want to fight for.

Susetiawan also confirmed that the social relationship between the bourgeoisie (the employer) and the proletariat (employees) contains fundamental conflict because their relationship is one-sided and exploitative. ${ }^{6}$ The relationship gap, Marx said, is sharpened by industrialization. In industrialization, entrepreneurs as owners of factors of production are getting rich while the workers remain in poor condition. ${ }^{7}$ The relationship between employees and employers is a relationship of power because there is a master (employer) and the ones mastered (employees). According to Ritzer, power always strictly separates between rulers and the ruled. Ruling class tends to maintain power, while the ruled is constantly trying to make changes. ${ }^{8}$

Gaps in industrial societies due to unequal relationship between the bourgeoisie and the proletariat cause the industrial conflict that Marx referred to as the basic conflict. Basic conflict can be strengthened when it is getting external influences (political, economic, social), so that to a certain extent it can develop and become actual. ${ }^{9}$

Therefore, it is clear that the conflict in industrial societies or industrial relations conflict is one embodiment of disputes over rights and interests. It is as proposed by Supomo that disputes in industrial relations are divided into two, namely conflict of interest, and conflict of rights due to the absence of mutual understanding about labour relations, working conditions and/or state of labour. $^{10}$

With the unequal profile or character of industrial relations, Rawls's theory of justice is

\footnotetext{
Marx in Irving M. Zeitlin, 1995, Memahami Kembali Sosiologi, Universitas Gadjah Mada, Yogyakarta, pp. 21-25.

Susetiawan, 2000, Konflik Sosial, Kajian Sosiologis Hubungan Buruh, Perusahaan dan Negara, Pustaka Pelajar, Yogyakarta, p. 11.

Hariyanto, 1991, Elit, Massa dan Konflik, PAU - Studi Sosial, Universitas Gadjah Mada, Yogyakarta, pp. 53-54.

George Ritzer, 1992, Sosiologi Ilmu Pengetahuan Berparadigma Ganda, Rajawali Press, Jakarta, pp. 31-32.

Stephen K. Sanderson, 2003, Makro Sosiologi, Sebuah Pendekatan terhadap Realitas Sosial, Raja Grafindo Persada, Jakarta, pp. $49-51$.

Imam Soepomo, 1992, Pengantar Hukum Perburuhan, Djambatan, Jakarta, pp. 96-97.
} 
relevant to talk about, especially with regard to the principle of justice in times of unequal socioeconomic position among the society. In connection with such injustice, Rawls argued that socioeconomic inequalities should be arranged so that the most vulnerable groups are the most advantaged. The people with least chances are to be given a higher chance. Departing from Rawls's principle of justice, employees who are in a weaker position than the employer need to be guaranteed protection by the employer. It can be a balancing tool for the unequal relationship between employees and employers. ${ }^{11}$

In order to accommodate such things, according to Seidman, it depends on the role played by the state. The accomplishment of such task in complex social conditions is not easy to do in developing countries that are at the intersection between the demands of society and the needs of economic development. ${ }^{12}$ The issue is whether the state can afford to be neutral and objective addressing the different interests or give preferential treatment to certain groups in industrial relations. The next issue is to whom the state will take side, because the state is also an actor in industrial relations, having clear interest in managing industrial relations.

In this regard, Organski has connected a link between the stages of development and the function of law in a state. According to Organski, there are 3 stages of development, each of which has the characteristic of a different emphasis to each other. First is the stage of unification, which is an early stage in the process of seeking national unification. The unification of the nation's ethnic groups' different commitment is a step towards political stability, while political stability is a prerequisite for achieving welfare state. Second is the phase of industrialization. At this stage, the state focuses its efforts on economic growth through capital accumulation, to which high economic growth is also a welfare state prerequisite. Third is the stage of national welfare, where the state realizes that industrialization is not always positive. At this stage, the state begins to try correcting the negative implications of industrialization by protecting the weaker sides. ${ }^{13}$

If related to the theory given by Organski, developing countries in general are only at the stage of industrialization, so that employees are generally suppressed or sacrificed for the success of economic growth. The development of law in developing countries is characterized by the dominance of the state's role, thus more driven to an increase in capital accumulation. Products of law in the industrialization are commonly unfair to employees. In practice, a wide choice of justice that could be used in particular conditions is not an easy thing to be realized, because it depends on many factors used as the foundation. In the end, the existing social reality determines the kind of justice that should be used. Such matters will eventually affect the law resulted.

\section{Justice Dilemma and Legal Certainty}

Rawls's theory of justice is not without criticism or conflict in practice, and one of those is with legal certainty. The law tries to give a concrete answer to the needs of society and at the same time intends to seek certainty, expediency and fairness. However, it should be noted that the certainty of the law can still be weakened, either by its own vagueness or change. ${ }^{14}$ The concept of "legal certainty" includes a number of interrelated aspects, and the protection afforded to the individual against arbitrariness other individuals, judges, and administrative (government) is one of those aspects. Legal certainty should be able to be linked with individuals regarding what can be expected of individuals will be done by the rulers, including the

Rawls, Op.cit., pp. 318-319.

12 Robert B. Seidman, 1972, Law and Development, General Model, in Law and Society Review, Wardsworth Publishing Company, California, p. 185

Organski in Wallace Mendelson, "Law and Development of Nations", The Journal of Politics, Vol. 32, 1979, p. 223.

14 H. Drion, 1981, Het Rechtszekerheidsargument, in: Hanteerbaarheid van het Recht, Bundel Opstellen Opgedragen aan Mr. L.D. Pels Rijcken, Boekenreeks NJB 7, Zwolle, p. 3. 
belief in the consistency of the decisions of judges or administrative government. ${ }^{15}$

In practice, legal certainty is not immediately true and adequate for the parties to a legal relationship, given that the threat to certainty is "the unpredictable behaviour of human beings (van het zijn toekomstig gedrag medemens)", as Nieuwenhuis has said. ${ }^{16}$ Legal certainty does not always result in justice, as it may be useful to ascertain how much weight can be given in a particular case. Of various situations, legal certainty can only be applied case by case. The weight of argument for legal certainty in many cases differs from each other according to their sizes, which in turn will vary according to the time and place of the occurrence of such cases. Different juridical arguments or a variety of methods for legal finding will be applied, so that in addition to legal certainty, the final decision of the court will also be based on considerations of justice.

Justice is something to be addressed by or through the law. This particular definition contains a broad meaning. ${ }^{17}$ The hypothesis of putting justice as the purpose of the law is useful, depending on how justice is understood. The above is evidence that the existing law is not always adequate to manage or resolve all the issues that may arise among the people. If there is not a rule applicable to a certain situation, the law will still have to give a fair verdict or settlement for it. All rules, both obligatory and constitutive, or other types as made by men, have the function of serving the interests of society. The rule of law includes the aspect of legal certainty and must also meet the needs of justice, given the trend to develop a "fairer" law.

Not only court decisions have to be applicable in the legal system, but also their contents must be accepted by the society. In general, the law aims to provide a fair settlement. ${ }^{18}$ However, the equal treatment of similar cases should not always be considered fair, because implicitly equating it can also bring injustice. Justice should not be interpreted merely formal, because if so, a similar treatment to a similar case will be undoubtedly considered as a fair treatment. Nieuwenhuis ${ }^{19}$ wrote: "Of justice as a formal category that suggests similar treatment (to the same case) must be added the material criterion which in turn can be the basis for a balancing assessment pattern". However, it is not easy to establish a material criterion that can be assumed and done with "measurements" to "equal treatment". It is the people who should determine which value pattern should be the basis for the determination of the material criterion. ${ }^{20}$ If for a particular issue the available legal rules cannot provide certainty or settlement, there would still be available legal principles that can give meaning to the given rules. Principles of law are the cornerstone of thought, which influenced the pattern of acts and can also function as a pattern of values in order to interpret the rules of law. However, it should be noted here that the norm can be said to be properly enforced only if the result is propriety. ${ }^{21}$ Not only the propriety in concrete to be considered here, but also other values such as the general public.

From the above description, a number of questions can be raised about the concept of typical Indonesian justice. The relationship between justice and legal certainty are always depends on culture and it should be considered different from one case to another. The concept of justice, which can be divided into procedural and substantive concepts, is embedded and rooted in the condition of the society. The procedural concept of justice is with respect to the legal system, the rule of law or state law.

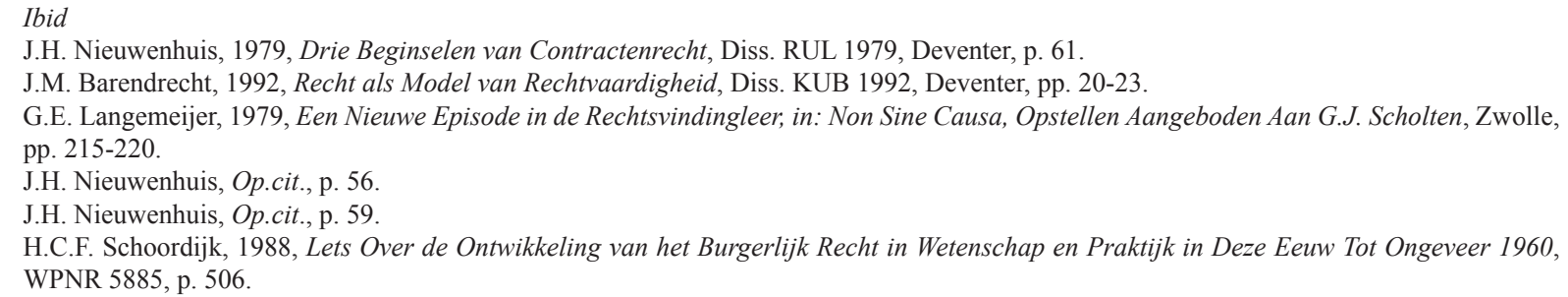


In contrast, substantive concept is with respect to the so-called social conditions. Substantial justice concept gives an overview of what and how the legal politics and legal awareness of the society is. The relationship between these two concepts depends on the choice of the legitimacy of the applied common life principles or by establishing a pattern of values as a foundation for substantive criterion for the concept of justice. As for the people of Indonesia, the common life is based on the principle of Pancasila.

\section{Potential for the Circumstantial Abuse in Industrial Relations}

Rawls's theory of justice in practice is also difficult to implement because of the potential for the circumstantial abuse in industrial relations, which is a doctrine developed to obtain equality. The purpose of the doctrine of circumstantial abuse is to ensure that the influence of one person over others is not abused. Lord Nicholls of Birkenhead state defines abuse as "one of the grounds of relief developed by the courts of equity as a court of conscience. The objective is to ensure that influence of one person over another is not abused". 22

Circumstantial abuse occurs when the person that knows or should have known that other people are in special circumstances such as dependent and inexperienced, moves another person to perform an action, in which it raises a legal act, though he knew or should have known that the action would harm others. It is not solely related to the contents of the agreement, but more in touch with what is happening at the birth of the agreement, the misuse of which leads to a statement on its own will and a party's ability is disabled. Circumstantial abuse concerns situations that play a role in the event of legal relationship, in this case the employment contract between employees and employers, which leads their will to not be freely used.

Circumstantial abuse basically consists of two elements, which are the cause of huge losses for one party and the abuse of opportunity. The element of opportunity abuse raises the appearance of two characters: economic and psychological advantages abuse. In industrial relations in developing countries such as Indonesia, such conditions occur because of the imbalance in potential labour supply and demand. This further strengthens because of the weak law enforcement and economic instability. An act is said to be abusing economic advantages, where one party has an economic advantage over the other and the other party is forced to hold the legal relationship of the parties in the form of agreement that has the economic advantage. It would be regarded as an act of psychological abuse if there is any relative dependence of one party and the other party abuses other party's circumstance for its own interests. ${ }^{23}$

Therefore, there are two formulas that can be used as indicators of circumstantial abuse. First, loss formula, where one aspect of an agreement made on the basis of circumstantial abuse causes damage to any of the parties. Second is profit formula, which looks from the opposite side, that the agreement in question provides benefits for the other party in excess. Both of these formulas are complementary. In a circumstantial abuse, one of the parties must have executed the agreement despite knowing that it should not be carried out. It is also important to note that in the circumstantial abuse, there is a causal relationship that without abusing the circumstances, the agreement will not happen. This is because there is a subordinate relationship between the parties in relation to the law.

Determining whether a legal act contains circumstantial abuse is not easy. This is because in everyday life, people often seek to influence the decisions of others, including the decision to take legal actions such as creating employment agreement. In certain circumstances, there are

22 Nelson Enonchong, 2006, Duress, Undue Influence, and Unconscionable Dealing, Sweet and Maxwell, London, p. 81.

23 Van Dunne in Henry P. Panggabean, 2001, Penyalahgunaan Keadaan (Misbruik Van Omstandigheden) Sebagai Alasan (Baru) untuk Pembatalan Perjanjian (Berbagai Perkembangan Hukum di Belanda), Liberty, Yogyakarta, p. 44. 
no issues with the influence exerted, but in other conditions, the effect of the law is unacceptable and considered as circumstantial abuse. Rawls's justice theory is relevant to the issue of circumstantial abuse. Rawls's opinion, saying that the fair law when equality is difficult to realize should side with the group that is weak economically and psychologically, is indeed difficult to achieve in practice. That is exactly the weakness of Rawls's theory in practice.

Although normatively or textually all the workers in the industrial relations are granted their rights and given legal protection, but they are not automatically entitled to use and maintain their rights if violated. There are always factors that influence people to behave in certain ways or not. It is possible that if the factors that affect is not a legal factor.

The issue of justice is the preference of value issue, something preferable and is an option. As an option, the value of justice may be built on the rationality of thought or just be a momentary emotional decision. Even though the circumstantial abuse provides opportunities for employees to cancel the agreement because it is considered as a defect of the will, it seems psychologically and economically difficult for employees to deal equivalently with their employers. That being said, Rawls's theory of justice is indeed weak in practice, especially in the practice of industrial relations.

The condition between Rawls's justice theory and its implementation in industrial practice gives an illustration of how the rules of the Labour Law are in the dynamics of interacting in society. The rules of law do not apply in a vacuum, but rather live in a particular social context. There is a dimension of space and time that should also be noted. If it is seen that the effectiveness of the enactment of the law is in the sociological phase, it seems difficult to implement Rawls's theory in industrial relations into something that is not too difficult to understand.

\section{Conclusion}

As a theory, the concept of justice Rawls has offered the idea enough to address confusion when faced with the two actors, two bargaining positions and two diametrically opposed interests. Rawls has explicitly provided an adequate answer by giving priority to people who are socio-economically disadvantaged, including in industrial relations. Law, according to Rawls, should be oriented to marginalized groups. In the context of industrial relations, employees have experienced various exploits with all the modifications that led to the subordinate position. However, as a product of politics, the law may not be neutral or sterile from various conflicts of interests in it, including that it will not be separated from the state's development paradigm. The state's economic development will be the basis and reference in the law-making process. Lawmakers have no choice but to be guided by certain interests in economic development policy. Therefore, Rawls's justice theory that gives place to marginalized groups such as employees, in practice will have difficulty in its implementation, particularly in developing countries that still favours industrialization, such as Indonesia.

\section{REFERENCES}

\section{A. Books}

Barendrecht, J.M., 1992, Recht als model van rechtvaardigheid, Diss. KUB 1992, Deventer.

Drion, H., 1981, Het Rechtszekerheidsargument, in: Hanteerbaarheid van het Recht, Bundel Opstellen Opgedragen aan Mr. L.D. Pels
Rijcken, Boekenreeks NJB 7, Zwolle.

Enonchong, Nelson, 2006, Duress, Undue Influence, and Unconscionable Dealing, Sweet and Maxwell, London.

Gie, The Liang, 1982, Teori-Teori Keadilan, Supersukses, Yogyakarta. 
Hariyanto, 1991, Elit, Massa dan Konflik, PAU - Studi Sosial, Universitas Gadjah Mada, Yogyakarta.

Langemeijer, G.E., 1979, Een Nieuwe Episode in de Rechtsvindingleer, in: Non Sine Causa, Opstellen Aangeboden aan G.J. Scholten, Zwolle.

Nieuwenhuis, J.H., 1979, Drie Beginselen van Contractenrecht, Diss. RUL 1979, Deventer.

Panggabean, Henry P., 2001, Penyalahgunaan Keadaan (Misbruik Van Omstandigheden) Sebagai Alasan (Baru) untuk Pembatalan Perjanjian (Berbagai Perkembangan Hukum di Belanda), Liberty, Yogyakarta.

Rawls, John, 1971, A Theory of Justice, The Belknap Press of Stanford University Press, Cambridge, Massachusetts.

Ritzer, George, 1992, Sosiologi Ilmu Pengetahuan Berparadigma Ganda, Rajawali Press, Jakarta.

Sanderson, Stephen K., 2003, Makro Sosiologi, Sebuah Pendekatan terhadap Realitas Sosial, Raja Grafindo Persada, Jakarta.

Schoordijk, H.C.F., 1988, Lets Over de Ontwikkeling van het Burgerlijk Recht in wetenschap en
Praktijk in Deze Eeuw tot Ongeveer 1960, WPNR 5885.

Seidman, Robert B., 1972, Law and Development, General Model, in Law and Society Review, Wardsworth Publishing Company, California.

Shaw, Bill and Art Wolfe, 1991, The Structure of Legal Environment: Law, Ethics, and Business, PWT- Kent Publishing Company, Boston.

Soepomo, Imam, 1992, Pengantar Hukum Perburuhan, Djambatan, Jakarta.

Sutrisno, F.X. Mudji, 1993, Manusia dalam PijarPijar Kekayaan Dimensinya, Kanisius, Yogyakarta.

Susetiawan, 2000, Konflik Sosial, Kajian Sosiologis Hubungan Buruh, Perusahaan dan Negara, Pustaka Pelajar, Yogyakarta.

Zeitlin, Irving M., 1995, Memahami Kembali Sosiologi, Universitas Gadjah Mada, Yogyakarta.

\section{B. Articles of Journal}

Mendelson, Wallace, "Law and Development of Nations", The Journal of Politics, Vol. 32, 1979. 